\title{
Research on Conflict and Cooperation of Agricultural Products Marketing Channel in Yunan Province
}

\author{
Fei HU \\ The Business School \\ Yuxi Normal College \\ Yuxi, Yunnan, China, 653100 \\ hfei@yxnu.net
}

\author{
Muqing PENG \\ The Business School \\ Yuxi Normal College \\ Yuxi, Yunnan, China, 653100 \\ pengmq@yxnu.net
}

\begin{abstract}
First of all this article made a literature review on agricultural product marketing channel relationship, then analyzed the relationship between farmers, middlemen and government in agricultural product marketing channel by taking Yunan province as an example, finally summed up the current problems existed in such channel and put forward some strategies to harmonize the channel relationship.
\end{abstract}

Keywords- Agricultural product, Marketing channel, Relationship, Yunan province.

\section{INTRODUCTION}

This article mainly focused on fresh agricultural products, such as, vegetable, fruit and so on. The agricultural product marketing channel specified in this research refers to a multidimensional aggregation, which including all organizations in the distribution process from producers to consumers and all the relative paths passed by, the flows achieved and variety of exchange relationships.

The research on foreign agricultural product marketing channel relationship mainly concludes three stages as following.

First stage (The middle and later period of $20^{\text {th }}$ century): Alderson, Stern, Brown and other scholars mainly focused on the research of power and conflict of channel.

Second stage (From the end of $20^{\text {th }}$ century to the early of $21^{\text {st }}$ century): It mainly focused on the study of agricultural product marketing channel relationship and system, which represented by Stern, Heide, F.E. Webster and Reve.

Third stage (Since $21^{\text {st }}$ century): Research on the virtual integrated structure of marketing channel based on market orientation.

Marketing channel behavior research is an important field of channel theory, which aims to study how the channel members recognize, establish and deal with the channel relationship. While western channel behavior theory is focus on how the members establish and use the power, dispose conflict and achieve competitive advantages through cooperation.

Channel relationship specified in the early stage of marketing study only refers to trading or exchange relations of channel. Since the relationship marketing paradigm was put forward, the definition of channel relationship started to be expanded from the discrete trading relationship to the continuous system of trading, which involving several types, such as cooperation, contract, management and convention. After the reform and opening-up in the last century, scholars in China mainly made researches by combining with practical situation and introducing western channel relationship theory, which has gradually become one of the hot topics of marketing channel research in China.

\section{ANALYSIS ON MARKETING CHANNEL RELATIONSHIP OF AGRICULTURAL PRODUCT IN YUNAN PROVINCE}

At present, the most typical and universal mode of agricultural product marketing channel in Yunan province is long channel mode with multistage intermediate links, the structure is as following: agricultural product producer(farmer)-origin wholesaler-wholesaler from marketing place-retailer-consumer.

However, the traditional short channel mode still widely exists in the rural area of Yunan province, which has a structure as below: agricultural product producer (farmer)consumer, i.e. farmers delivery variety of primary agricultural products they planted or raised to the pedlars'market and sell to consumers directly, which is similar to the direct selling mode.

In additional, an intermediate mode is also existed, which formulated the coexistence of long and short marketing channel of agricultural product in Yunan province consequently. The structures mentioned above not only including the main body of channel that researched by channel theory, such as, agricultural product producer (farmer and agricultural enterprise), middleman (agricultural agent, wholesaler, retail enterprise, retail vendor, agricultural circulation enterprise and individual operator), but also contains the channel participant, such as, consumer and government.

\section{A. Relationship between agricultural product producer and middleman}

Actually speaking, the channel power structure is seriously inclined to middleman in the relationship between farmer and middleman. Firstly, the trading volume occurred between farmer and middleman is nearly the total income of farmer, however, the proportion of those agricultural product supplied by specified farmers in the whole products 
purchased by leading enterprise is extremely small, which caused a strong dependence of farmer to leading enterprises.

Secondly, due to the homogeneity of agricultural product, middlemen think that the farmers who produce same product can be absolutely replaced. But for farmers, the middleman for purchasing and processing specified product is relatively scarce, so they don't have too much choice and have to depend on middleman more fiercely. Combined with enterprise's advantages on the aspect of market information and product inspection, farmers' strong dependence on middleman enable them to take the leading position in such channel relationship.

According to the investigation of tomato price in Yuxi and Kunming city of Yunan province, this article summarized the value activities and profit status of each subject in the channel of "Farmer-supplier-supermarketconsumer" based on the research data and analyzed the profit of each subject as per value chain analysis method as following.(please refer to table 1)

Table 1 Tomato's value-added structure in channel of "Farmer-supplier-supermarket" (Yuan/kg)

\begin{tabular}{|c|r|r|c|}
\hline $\begin{array}{c}\text { Value-added } \\
\text { structure }\end{array}$ & $\begin{array}{c}\text { Far } \\
\text { mer }\end{array}$ & $\begin{array}{c}\text { Supp } \\
\text { lier }\end{array}$ & $\begin{array}{c}\text { Superma } \\
\text { rket }\end{array}$ \\
\hline $\begin{array}{c}\text { Purchasing price } \\
\text { ( Production or } \\
\text { purchase cost) }\end{array}$ & 3.00 & 3.50 & 5.67 \\
\hline $\begin{array}{c}\text { erage } \\
\text { selling } \\
\text { price }\end{array}$ & 4.10 & 5.67 & 7.20 \\
\hline $\begin{array}{c}\text { Added value } \\
\text { Additional cost }\end{array}$ & 0.03 & 0.16 & 0.06 \\
\hline Profit & 1.07 & 2.01 & 1.47 \\
\hline Value-added & 23.4 & 44.08 & $32.31 \%$ \\
\hline proportion $\%)$ & $6 \%$ & $\%$ & 1.53 \\
\hline
\end{tabular}

After analyzed the above table, the value-added relationship distributed for different agricultural product marketing channel subject can be summarized as below, producer (farmer) only takes $24 \%$ while the middleman occupies $76 \%$ of the added value.

Farmers can get the maximum profit in case they go to market and sell the product directly. Actually, in order to prevent the agricultural product from decaying because of dead stock, they think it is much more convenient to sell the product to suppliers one time by a lower price due to inconvenient traffic, time consuming, lacking of labors, and difficulty in grasping the market trading information. The appearance of such kind of cooperative behavior is a great marketing progress of farmer, but the conflict is still inevitable. Although the middleman has the absolute dominance in the channel relationship of "Farmermiddleman-consumer", this feature is not always shown in the practical operating. As the contract signed by farmer and middleman can not get rid of influences to the price of agricultural product from other factors, such as, natural and economic factor, it is possible that one of the parties will break the contract during trading process.

If the current marketing price of the agricultural product is lower than the purchasing price regulated in contract, the farmers will be glad to cooperate. Conversely, if the marketing price is higher than the purchasing price, the farmer is very likely to break the contract. Although the middleman has strong power and always dominates in the bargaining, their default cost is relatively higher, but the single farmer has a little default cost although he is often on a weak position. Based on the dispersity and large quantity of default farmer, the profit of middlemen will be greatly lower than the litigation cost even though they win the litigation. In this case, middlemen always have to tacitly approve it if such kind of conflict happened, and their dominant power to farmer will be invalid as well.

Based on the above analysis, we can get a rule as below. As the basic unit of agricultural production, single farmer is on a wear position by facing with the relatively powerful middlemen after entered into the agricultural market and has to accept the price passively. Compared with wholesaler and retailer, the production cost of farmer is highest, they not only have the longest time for investment, but also have biggest operation risk, however, they often get the least money. This non-equivalent channel relationship is just the main reason to destroy the channel cooperation and result in channel conflict.

\section{B. Relationship between agricultural middlemen}

In general, regional natural monopoly is visible in the middle circulation market of agricultural product. The middleman who dominant all the links of market channel in one region should invest a lot primary cost, maintenance cost and upgrading cost during the supply chain process of establishing and maintaining "Forward integration" and "Backward integration" between each other. Once the marketing channel is setup and operated, "Access barrier" with high cost will be developed for potential entrant outside the system and an "Exit barrier" will be formulated to the middlemen inside the system at the same time.

For this reason, middlemen must grow up and create their size and economic advantages. With the structure of regional and natural monopoly, monopoly pricing in the middle links of marketing channel can be achieved by middlemen, then the farmers will become the passive recipient of purchasing price of agricultural product while the final consumer is the passive recipient of retail price, in this case, middlemen will be able to get higher profit. Agricultural middlemen including agent, wholesaler, retailer and so on, which has diversified behavior features (it is multi-subject internally and just a whole externally). In order to get the pricing power against outside, they are likely to cooperate with each other and make a uniform price level under certain circumstances. Of course, in order to try to get a higher profit, strong competitions are existed among each middleman in the channel, but the precondition is not to destroy the pricing 
power against outside. Therefore, the relationship between middlemen is more inclined to cooperation, not conflict.

\section{Relationship between consumer, government and agricultural product marketing channel.}

Consumer and government is not the emphasis of channel research, but there is a relationship between them and channel. The consumers are scattered although the quantity is big, so it is difficult to develop an effective union among consumers to change the "Middlemen pricing mechanism" at present. From a general view, agricultural product is just the necessity of life for consumer and the flexibility of demand price is small. Consumers' option is seriously constrained as there is no pricing advantage and lack of flexibility of agricultural product, so they are often on a weak position in the marketing channel and become the passive recipient of the retail price. Consequently, consumers have to cooperate with middlemen even though they are not willing to. However, the crisis of conflict is still hidden behind such passive cooperation.

As the regulator of microeconomic, government conduct regulation to agricultural product marketing channel through a series of economy and law means and policies, such as, supervise and regulate the price of agricultural product, establish and manage the agricultural market, protect the benefit of farmer and consumer, which are aim to maintain the stability, order and effective operation of agricultural product marketing channel.

\section{PROBLEMS EXISTED IN THE MARKETING CHANNEL RELATIONSHIP OF AGRICULTURAL PRODUCT IN YUNAN PROVINCE}

The problems of agricultural product marketing channel in Yunan province can be summarized based on the above analysis. The channel subject (such as farmer, middleman, consumer, government) and participant use their own power in the agricultural product marketing channel and develop variety of interaction relationships (such as, conflict and cooperation) from the perspective of the rational pursuit of self-interest. At present, the conflict among the members of agricultural product marketing channel in Yunan province is bigger than cooperation, especially the conflict between farmer and middleman. The profit distribution for farmer and consumer is small while the middlemen get the most benefit. The channel conflict is mainly caused by lower organizational degree of channel member. At present, the contradictions between small farmers, petty dealers and big market have not been solved yet and the channel members did not cooperate with each other closely.

Firstly, farmer is on a weak position as the lower organizational degree, which caused the unbalanced power structure in the channel and result in conflict and instability of channel.

Secondly, the channel opportunism is prevailed due to the lower opportunism penalty cost of small size channel member.

Channel member often conduct short term trading as the small farmer, petty dealer and other non-modern enterprises occupy the primary position of channel, most of them are lacking of common planning for future and they are not willing to try best to maintain the valuable cooperative relationship between each other.

Finally, profit conflict is frequently occurred among channel members as the profit mechanism (share of risk and profit) has not been formed between the subjects of channel, which will further lead to the insufficient trust between each other and the failure of effective trust mechanism. Moreover, they can not establish a reliable cooperation or even can not conduct an effective integration and coordination for each channel activity due to such untrusted behavior.

All the reasons mentioned above lead to the low cooperation level of agricultural product marketing channel and unstable channel relationship in Yunan province.

\section{COORDINATION FOR AGRICULTURAL PRODUCT MARKETING CHANNEL RELATIONSHIP IN YUNAN PROVINCE}

Regarding the views on conflict and performance of marketing channel, the so called "Conflict-performance" hypothesis is dominant in foreign country at present, and the core concept is that conflict will reduce the performance of channel. A basic consensus formed in China is that, agricultural product channel conflict will inevitably result in the decrease of channel performance. The more common channel conflict is, the lower channel member satisfaction with the channel relationship will be.

At the same time, it is necessary to promote and guide the majority of farmers, leading agricultural enterprises and agricultural product dealers to create a shared goal and develop profit mechanism ("Share the risk and profit"), then establish a channel union based on information sharing, mutual trust and long term cooperation. The fundamental operating target of agricultural product channel union is "Win-win cooperation" and the basic mechanism is cooperation mechanism. The essence of establishing the relationship and union of channel member is to lead the integration development of agricultural product marketing channel, which is the main orientation and irresistible trend of modern agricultural product marketing channel development.

The main resource of channel power are including reward, penalty, referent, expert and law power (Stern, 2001), which can be classified into two types as per dichotomy, such as, coercive power and non-coercive power. A great deal of research results show that, overuse of coercive power will lead to conflict and decrease the willing of cooperation, while non-coercive power is enable to reduce the conflict and increase the willing of cooperation. The establishment of relationship and union of channel member can make the agricultural product marketing channel have an integrated development and better utilize the dependence, trust, promise and other non-coercive power among the members to enhance the intention and stability of their cooperation.

The higher dependence among channel member, the fewer channel conflict it will be. If both the sides of channel have a strong dependence of other side, it will be helpful for the stability of channel, and they will consider from the view 
of long term profit to reduce the opportunistic behavior and create high level of cooperation, trust and promise. However, the party who own specialized asset is likely to depend on other party, because the specialized asset will be invalid or undervalued in case the cooperation is hard to be continued as the other party break the contract. In order to create the relationship and union, channel members are necessary to make special assets investment, so that the dependence relationship between each other can be strengthened. In general, the establishment of channel member relationship and union and the leading of integrated development of agricultural product marketing channel are conducive to improve the channel performance of members and help them to share the channel profit together during the process of good cooperation.

\section{CONCLUSIONS}

In additional, it is necessary to intensify the consumer benefit union and government regulation in order to decrease the channel conflict, enhance channel cooperation and maintain the stable running of agricultural product marketing channel.

\section{Reference}

[1] Zhuang Guijun, Power conflict and cooperation: Western channel behavior theory $[\mathrm{J}]$. Journal of Beijing College of Commerce, 2000 (1):8.

[2] Li Chuncheng, Li Chongguang. The influence of channel conflict to channel performance-Take the market investigation of fresh agricultural product as an example [J]. China Business and Market. 2010, (12):52.

[3] Li Lianying, Discussion and evaluation of marketing channel cooperation [J]. Journal of East China University of Science and Technology (Society and science edition), 2012, (9):229.

[4] Hu Guyue, Xu Ming, Research on relationship between dependence and conflict of principal-agent model to agricultural product marketing channel $[\mathrm{J}]$. Hei Longjiang agricultural science, 2010, (12): 134-136.

[5] Hu Huaping, Research on evolution and development of agricultural product marketing channel [D]. Wuhan: Huazhong Agricultural University, 2011:25-26.

[6] Qing Ping, Research on conflict of agricultural product marketing channel [D]. Wuhan: Agricultural University, 2007:6-10.

[7] Li Chuncheng, Research on evaluation and compare of agricultural product marketing channel performance [D]. Wuhan: Huazhong Agricultural University, 2007:63.

[8] Zhao Xiaofei, Research on problems of agricultural product marketing channel union in China [D]. Wuhan: Huazhong Agricultural University, 2011:17. 